\title{
DEVELOPING CULTURE-BASED ENGLISH LEARNING MATERIAL TO SUPPORT THE IMPLEMENTATION OF CURRICULUM 2013 FOR THE FIRST SEMESTER OF GRADE SEVEN JUNIOR HIGH SCHOOL IN BULELENG
}

\author{
A. Fitri ${ }^{1}$, I. G. Batan ${ }^{2}$, N. W. S. Mahayanti ${ }^{3}$ \\ Jurusan Pendidikan Bahasa Inggris \\ Universitas Pendidikan Ganesha \\ Singaraja, Indonesia
}

\begin{abstract}
e-mail: annisa.fitrie@rocketmail.com ${ }^{1}$, igd.batan@yahoo.com ${ }^{2}$, mahayantisurya@yahoo.co.id ${ }^{3}$
\end{abstract}

\begin{abstract}
Abstrak
Penelitian ini bertujuan untuk mengembangkan materi ajar Bahasa Inggris berbasis budaya lokal dalam mendukung implementasi kurikulum 2013 untuk semester pertama kelas 7 sekolah menengah pertama di Kecamatan Buleleng. Penelitian ini dikembangkan berdasarkan model penilitian dan pengembangan dari Peffers dan kawan-kawan dalam Ellis dn Levy (2010) yang terdiri dari 6 tahap umum, yaitu: 1)mengidentifikasi masalah, 2) mendeskripsikan tujuan, 3)mendesain dan mengembangkan produk, 4)mengetes produk, 5)evaluasi produk, dan 6)mengkomunikasikan produk. Agar mendapatkan hasil produk yang maksimal, evaluasi produk dinilai oleh dua ahli untuk mengevaluasi kualitas dari isi, integrasi budaya lokal, dan presentasi dari materi Bahasa Inggris yang berbasis budaya lokal.Instrumen yang digunakan dalam mengevaluasi hasil produk ahli yang berupa checklist.Semua data yang terkumpul di analasis secara kuantitatif dan secara kualitatif.Hasil dari penelitian ini berupa Buku Bahasa Inggris berbasis budaya lokal dalam mendukung implementasi kurikulum 2013 untuk semester pertama kelas 7 sekolah menengah pertama di Kecamatan Buleleng.Buku ini terdiri dari 4 tema umum.Materi di desain secara cermat berdasarkan konteks budaya Bali.Konteks budaya Bali dalam buku ini diselipkan melalui gambar, dialog, dan kegiatan pembelajaran.Buku Bahasa Inggris berbasis budaya ini juga didesain berdasarkan karakteristik dari kualitas buku.Aspek tersebut dapat dilihat dari topik, aspek dari budaya lokal, dan presentasi buku yang didesain khusus untuk memenuhi kriteria kualitas sebuah buku dari Tomlinson (1998).Secara umum, para ahli menyatakan bahwa buku bahasa Inggris berbasis budaya lokal sudah menarik dan sesuai dengan kriteria yang disertakan.
\end{abstract}

Kata Kunci: Materi Bahasa Inggris, materi Bahasa inggris berbasis budaya lokal

\footnotetext{
Abstract

This research aimed at developing culture based English learning material to support the implementation of curriculum 2013 for the first semester of grade seven junior high schools in Buleleng. This research was designed by utilizing an $\mathrm{RnD}$ model development proposed by Peffers et al in Ellis and Levy (2010). This model consisted of six general phases, such as: 1) identify the problem, 2) describe the objectives, 3 ) design and develop product, 4) test the product, 5) evaluate the product, 6)communicate the product. In order to reach the high qualified product, there were two experts evaluated the content of product, integration of local culture, and presentation of culture based English learning material in the form of English
} 
judgment form. All data were analyzed quantitatively and qualitatively. The result of this research was designed in the form of culture based English textbook to support the implementation of curriculum 2013 for the first semester of grade seven junior high schools in Buleleng. This textbook consisted of 4 topics. The material was designed carefully depends on Balinese culture context. The context of Balinese culture were integrated into pictures, dialogues, and learning activities. Culture based English textbook were also designed to meet the characteristic of good textbook by Tomlinson (1998). Generally, the two experts stated that the product were already interesting and appropriate with characteristic of good textbook.

Keywords: English learning material, culture-based English learning material

\section{INTRODUCTION}

Curriculum is dynamic because
always change depend on the
development and challenge of era
(Mufidah, 2014). Curriculum 2013 is the
latest curriculum that launched by
government. The purposes of the study
of the curriculum 2013 in the
classroom are not only based on what
student learned from curriculum, but
also to achieve certain values. The
religious values and some characteristic
building values in the student's
character are also taught in the
classroom. Curriculum 2013is actually developed from previous curriculum, that is why, the difference between this curriculum and the previous curriculum can be clearly seen from the format of the curriculum itself. Based on the purpose of the implementation of curriculum 2013, this curriculum is more emphasize on the development of students character building. The implementation of curriculum 2013 did not run well as government's expectation. In fact, after implementing curriculum 2013 for a year, there were many problems that faced by both the teacher and students; for instance, the difficulty in changing the concept about education paradigm for the teacher. The change of learning model from teacher centred to be students centred, made students should explore many resources to make them actively participated and easily construct meaning by themselves. Besides, the school's preparation in implementing the curriculum 2013 was unprepared well; meanwhile government has conducted several trainings in order to give detail information for teachers and schools related to curriculum 2013 . The government standardized the curriculum as the same one for every school in curriculum 2013, it means that there is not any differences for every school in Indonesia, in fact, the condition of schools are different each other. In addition, there were several aspect of education in Indonesia were not ready yet to implement this curriculum, for instance, the distribution of textbook does not run well. There were several schools get the books yet even when the teaching learning process had run for several months. As we now, textbook is one of important tools in teaching learning process. It becomes the reason why government back to change the curriculum 2013 into curriculum 2006 for the school that were applied the curriculum 2013 for one semester. Although the implementation of curriculum 2013 is still being polemic in Indonesia, there is an important point from curriculum 2013 that should be continued, that is character education. Character education is one way which is used to make a better education in Indonesia. it is also supported by Undang-Undang No. 20 Tahun 2013 Pasal 3 which explains that education has a function to develop and to build students' character, so the students can develop their potential and being a good human who have good moral, physically and psychologically healthy, skilful, creative, independent, and be democratic and responsible citizen. In curriculum 2013, character education emphasizes to all levels students especially for junior highs school students who categorize as young students. It is needed because junior high school students are in puberty period. Children who are growing up in puberty period are 
easier in adapting and influencing the situation or the environment where they grow up includes positive influences and negative influences. Children in that period commonly easier to adapt and adopt about what they see in her daily life, even it is negative things. Nowadays, there are many problem cases that are faced by all of the elements include government, parents, and children itself about children's negative problem. Those problems such as drug abuses, free sex, violence between children, bullying, cheating and other bad behaviour cases. Character education can be inserted in many ways, of them through integrating local culture into teaching learning process. According to Hinkel (1999) integrating culture into material is beneficial because the context of the culture is related to the students real life. It can make students easier to understand the materials. It also makes students remember about their own local culturein this globalization lifestyle. Hinkel (1999) also said that inserting local culture to the materials also promote character building because the moral value in the local culture can build better character on the students. The result of interviewing English junior high schools teacher related to the learning materials showed that all the English teachers answered that the concept of local culture is not inserted in their syllabus or lesson plan. Based on the result of the study, it showed very clearly that the students are not prepared well with local culture by the curriculum of English teaching and learning process. Through preliminary observation, all teachers agreed to insert Balinese local culture especially into English learning process, it is important in order to build students' character based on the culture where they live. Even though they all agreed, several teachers did not inserted Balinese local cultural aspects in their learning process because of the condition of students who have different background culture and the teachers were not ready to insert Balinese local cultural aspects in learning. There are several English teachers in some junior high schools in Buleleng already inserted
Balinese cultural aspects in English teaching and learning process by telling Balinese stories, using traditional Balinese food and beverages, and also by using several concepts of Balinese culture to motivate students in learning. However, the fact said different thing, learning materials which are used in English learning instruction in Buleleng do not contain Balinese local culture. English language learning should insert local cultural aspects, in this case Balinese culture, in order to build students' character. Inserting local culture in English learning is also important to support the development of character building. Besides, English learning materials that contain local culture can be easily learnt by the students, because they are familiar with those aspects. In short, Balinese culture-based English learning materials is needed to be developed for seventh grade students of junior high schools in Buleleng, since their learning materials do not contain Balinese local culture.

Based on the explanation above, this study designed and developed a culture based learning material for teaching English. Therefore, through this research, a culture based English learning material for first Semester Grade VII of junior high school is developed.

The problem in this study was "how culture-based learning material couldbe developed for seventh grade students of junior high school in Buleleng to support the implementation ofthe curriculum 2013?

The general purpose of this research is at designing and developing a suitable culture-based learning material for seventh grade students of junior high school in Buleleng in order to support the implementation of the curriculum 2013.

\section{LITERATURE REVIEW}

English Language teaching (ELT) is a teaching of English language to people whose English is as second or foreign language. . People whose native language is not English learn English for several purposes, for instance they learn English in order to reach the development of the globalization since English is used as 
international language. Sukarno (2012) says that the goal of English language teaching is making students are able to communicate using target language, in this case is English

Teaching and learning process cannot be separated from the learning materials. According to Ranjit (2010) Learning is a process of gaining and receiving knowledge of things in the world around us, through sight, sound, smell, taste and touch. According to Sungkono (2003:1) learning material is material which is arranged systematically based on learning principal used by both teacher and students in teaching learning process. Tomlinson (1998) stated that learning materials for language refers to anything which is used by teachers or students to facilitate the learning of a language, including course books, videos, graded readers, flash cards, games, websites and mobile phone interactions. In short, learning materials is developed as a product to help the students in understanding the material and help the teacher to provide the material easily.

According to Tomlinson (1998) there are several characteristics of materials that will become appropriate in learning process. Those several criteria are: (1) materials should achieve impact, (2) materials should help students to feel comfortable, (3) materials should help students to develop confidence, (4) materials should be relevant and useful for students, (5) materials should build students' self-investment, (6) materials should be suitable with students' level in learning, (7) materials should help students to use language authentically, (8) materials should cover linguistic features that can attract students' attention, (9) materials should provide opportunities for students to communicate by using target language, (10) materials should not force students' to produce something before they are ready, (11) materials should cover different learning style, (12) materials should cover students' affective attitudes, (13) materials should provide starting point in the beginning, (14) materials should increase students' learning potential, (15) materials should not control students too much, (16) materials should provide chance for feedback. National Ministry of Education (2004 as cited in Sudrajat, 2012) stated that there are 6 main steps that need to follow in developing learning material.

In this study, culture based material is one of the contextual instructional approaches that based on constructivism theory. Culture-based material here was learning material which consist of local cultures information to support implementation of curriculum 2013. Those local cultures and character values were divided into all of the themes and topic for the first semester of seven grade of junior high school. Tomlinson's criteria of good material and characteristic of curriculum 2013 by Bird were used as guidelines in developing culture based English textbook.

The phases of integrating local cultures into English learning material based on the curriculum 2013 are as follows: (1) identifying the problem through interviewing the teacher; (2) describing the objective through the result of need analysis discussing that classification with the teacher and the experts of socio cultural; (3) designing and developing the culture-based English learning material through analyzing syllabus, classifying the suitable local culture in supporting character building based on the core competence and basic competence, identifying the themes of developed book, exploring and elaborating local cultures into topic based on the syllabus, drafting, collecting material, and producing the product.

Some previous researches conducted to integrate local or native culture in English language teaching. For instance, a study conducted by Kirgoz and Akgam in 2011. That study investigated the cultural elements of locally published English textbook used for Turkish primary schools following two major curriculum innovations in ELT. The result showed that the representations of source culture, target culture and international target culture are favoured in locally produced ELT textbooks in a balanced way.

Kristiawan (2012) conducted a research in integrating local culture in ELT 
material design. There were four main issues that were discussed in that research; those were (1) topic selection, (2) the use of virtual aids, (3) learning tasks, and (4) materials evaluation. Besides, that research also discussed the implementation of integrating local culture in English language teaching classroom. Kristiawan suggested in situating local cultures in language material design, teacher should consider appropriate topic selection, visual media, learning tasks, and material evaluation. The result of this research showed that situating local cultures in ELT help students become aware of how their local culture enriches their linguistic resources and social practices, also making their language learning more meaningful.

\section{METHODOLOGY}

This research was conducted by using Research and Development (R\&D) design. A framework of Research and Development (R\&D) design proposed by Peffers et al. In Ellis and Levy (2010), Peffers et al. (2007) establish a framework of R\&D model which consists of six phases, including (a) identify the problem motivating the research (b) describe the objectives (c) design and develop the product (d) subject the product to testing, (e) evaluate the result of testing, and ( $f$ ) communicate those results.

The instruments used in collecting the data for this study were (1) document (2) field note (3) expert judgment form.

\section{FINDINGS}

\section{Identifying the Problem}

As the objectives of this research was to design and develop learning material to support implementation of curriculum 2013 for the first semester grade VII of junior high school in Buleleng. To complete this present study, need analysis was needed to be a foundation. Need analysis were gained from preliminary observation by conducting interview the English teachers in several junior high schools in Buleleng. The result of interview sessions would be used as guidance for the researcher in designing and developing English learning material which was appropriate with the students' level of grade seven of junior high school in the first semester. Based on the last point of interview which was the development of English learning materials needed in teaching and learning process, culture-based English textbook was chosen to be designed and developed in this study.

\section{Describing the Objective}

Describing the objectives of the research was conducted after identifying the problem itself. The objective of this research is how to insert the suitable culture-based learning material to support the implementation of curriculum 2013 for first semester of seventh grade students of junior high school in Buleleng.

\section{Designing and Developing the Product}

The result of need analysis which was done by the researcher through distributing interviewing the teacher became the basis in designing and developing Balinese culture-based English learning material to support the implementation of curriculum 2013.

Based on need analysis, artifact or product that suitable for teachers and seven grade students of junior high schools in Buleleng is textbook which is culture-based in order to support the implementation of curriculum 2013, and emphasizes more on character education.

That learning material was developed based on the characteristics of the syllabus used, and the criteria of good learning material proposed by Tomlinson also the basic standards of good textbook that were proposed by Badan Standar Nasional Pendidikan (2011). According to Badan Standar Nasional Pendidikan (2011), there are three aspects that should be focused on designing and developing good textbook, those aspects are content, presentation, and language.

Several activities conducted by the researcher in designing and developing the product. Those activities were (a) analyzing the syllabus (b) identifying Balinese Cultural Values (c) identifying the themes ( $d$ ) ways of developing Balinese 
local culture (e)drafting (c) collecting the materials, and (d) producing the product.

\section{Analyzing the Syllabus}

Designing and developing the culture-based learning material must in line with the development of the curriculum, syllabus, and fulfill the criteria of good learning material. This learning material developed in the form of textbook. In designing this textbook, document analysis was needed. It was done by analyzing the syllabus of curriculum 2013 of English lesson for seventh grade junior high school. The aim of analyzing the syllabus was to find out both the core competence and basic competence. Those competences were needed to establish the indicators for the learning materials.

Based on the analysis of syllabus for first semester of grade seven of junior high school, the first core competence is to develop students' religiousness, the second competence is used to develop students' social, the third and fourth core competences are combination competences that used to develop affective domain, cognitive domain, and psychomotor domain. Through those competences, indicators were established to indicate students' achievement in teaching and learning process.

\section{Identifying the themes}

There are four main themes in the development of culture-based English textbook for grade seven of junior high school. The themes were decided trough group discussion between the researcher, the supervisor, and the socio cultural expert. Those themes were arranged based on the core competences and basic competences. The themes chosen were classified from the material provided in syllabus. Balinese cultural values also became one consideration in choosing theme. The four themes are Balinese wedding ceremony for Unit 1, Ngayah for Unit 2, Melasti ceremony for Unit 3, and the last Balinese carving for unit 4.

\section{Ways of Integrating Balinese Local Culture}

After analyzing the result of validation of the relevancy between Balinese culture and character education, the researcher started to integrate the suitable Balinese culture and character values into textbook through pictures, places, clothes, Balinese artists.

\section{Pictures}

Several pictures were distributed in every themes or topics which were related to the topic. The pictures were chosen by the researcher appropriate with the students' daily life about what they see or what they used. Pictures in textbook were provided in order to get students' attention in learning. Those pictures also help the students to understand the material easily, because the pictures' provided were suitable with the context. Besides, the pictures in the developed culture-based English textbook were aimed to develop students' characters. The examples of pictures used in the developed culturebased English textbook were offerings, Balinese statues, Balinese temple, and so on.

2. Characters' name and characteristics of Balinese people

The representation of characteristic of Balinese people could be seen in the dialogues and reading passages. Most of dialogues present about Balinese people characteristic such as friendly, hard worker, honest, and discipline. Each dialogue gave the students positive values to adapt those characters. The character's name used also based on the Balinese people, such as Putu, Gede, Ngurah, Alit, etc. It was helpful for the students to understand the dialogue and reading passage because the content was contextual.

\section{Places}

The culture based textbook for grade seven of junior high school also provided several famous places in Bali, such as Bali Museum, Penglipuran Village, Sukawati Art Market, etc. The introduction of those places make students more interesting in learning English since them familiar with the places mentioned in the textbook. 


\section{Clothes}

The representation of Balinese clothes can be seen through pictures which were provided in the dialogue. Through those pictures, the students more interesting because those clothes were very close with their daily life.

\section{Drafting}

The next step was making a blueprint or drafting. Blueprint consists of core competence, basic competence, themes, and learning activities. Blueprint or drafting was used as the process in establishing the themes for the product, establishing the indicators for each theme, and creating the learning activities. There were four themes established for the product of this study. The themes are Balinese Wedding, Ngayah, Melasti Ceremony, and Balinese Carving. Themes established were based on the core competences and basic competences for grade seven of junior high school. Themes that established in line with the core competences and basic competences, and then the indicators were established to complete the themes and they were established based on the basic competences for each theme.

\section{Collecting Materials}

Materials used in developed textbook were designed from many sources. Blueprint was used as a guideline in making this book. Those pictures and texts were chosen to support the topic in textbook. Some pictures were made by the researcher in order to provide appropriate and suitable picture for students. The other pictures also taken from internet, at the end of textbook is provided by material resources to avoid plagiarism. Most of text include story, dialogue, conversation were made by the researcher in order to meet the appropriateness with the topic. Inspired story section was taken from internet.

\section{Producing the Product}

Process of designing layout and printing out the developed textbook is the process of producing the product. Layout of developed book was made colourfully and creatively to interact students' attention and to motivate the students in learning. The processor used in organizing the developed textbook was The Microsoft Word 2007 include the layout.

There are several general elements which are developed in this culture based English textbook. These elements are the use of the how to use this book page of the book to give the readers information about what the readers will find in the textbook, the front page to give such foreshadowing to the students about the material in a certain chapter and also the goal of learning, brainstorming page as early introduction about further material and also learning activities which are divide into five parts based on scientific approach of curriculum 2013and other interesting parts.

1) How To Use This Book Section

The textbook is completed with How to Use This Book section. In this textbook, that section intended to give brief information about the relation between themes, core competences, basic competences also provide what the readers will find inside the textbook. By this element, the reader can find much information about the textbook, and also the guidance to use the book effectively.

\section{2) Front Page}

Every unit in this textbook begins with a page that represents the whole materials that the students are going to learn. This first page is called the front page of the chapter. On the front page, the users of this textbook can find the name and title of a chapter and also goal of learning.

\section{3) Brainstorming}

Every unit in this culture based English textbook contains Brainstorming Section. This section is an introduction statement of the topic that will be discussed further. By this section, the reader will get general information of what material will be learnt in certain unit.

\section{4) Warming Up/Observing}

Warming up section provided listening section for the students in the beginning. In this listening section, the students try to observe the appropriate pictures with the appropriate sentences 
that they heard. Warming up section gave the students an activity that introduce them the material in each unit. It was very helpful to stimulus their prior knowledge to thing or guess what they are going to learn in each unit.

\section{5) Questioning Section}

Questioning is a second section in scientific approach of curriculum 2013. This section gave a chance for the students to practice their communicative skill because they were asked to ask their friend brief questions related to the topic and then they were asked to write the information that they got from asking their friend. By raising questions for their friend, students were trained to use English as well. It help the students to practice English in their daily life and contextually.

6) Exploring Section

Exploring section is a third activity in scientific approach. In exploring section, the developed book provide several activities in which have a function to give students examples related to language features that should be understood by students. In this section the students are asked to find the linguistic features including grammar and vocabulary.

\section{7) Associating Section}

Associating is the section where the students are going hand in hand with their friend. In this section, the students are associated about what they have learnt with their experience.

\section{8) Communicating Section}

The last section of scientific approach in curriculum 2013 is communicating. In communicating section, students were asked and given a chance to present or communicate their project in front of the class.

\section{9) Let's Make a Reflection}

Let's make a reflection session provides a guidance for students to summarize what they have learnt during the unit, what they like most and what they don't like in every unit, also the their improvement during learning the lesson. 10) Cultural Information Section

This section is additional cultural information related to the main topic. This part provides much important information that will be useful for students related to the material discussed. This give students extended information that will enrich their knowledge about Balinese culture in attractive way.

\section{1) Let's get Inspired Section}

The purpose of inserting this section into textbook is to provide students an inspirational person in dedicating his life for Balinese culture. This part is expected can make student at lest do same thing with inspirational person, so indirectly they learn and keep their local culture in a way.

\section{Testing the Product}

After finishing the textbook, the next step was getting validation from the judges who are expert in English language teaching, expert in curriculum development, and user. Validating of the product was done in order to see whether the product developed already fulfil the criteria of good materials or not. The test was conducted by providing validity form for expert judgment followed the description of evaluation point of English Textbook proposed by Puskurbuk in which the description already covers the criteria of good material by Tomlinson. A modified expert judgment for was conducted in order to cover the integration of Balinese local culture and character values.

The judges who validated this textbook were Dr. Ni Made Ratminingsih, M.A and I Gede Wimi Saputra, M.Pd. Mrs. Ratmi is a lecturer of English Education Department, Ganesha University of Education. She is an expert in English language teaching and curriculum development. The user is Mr. Wimi, an English teacher in SMP N 1 Singaraja. The validation done by scoring the book based on three components; content, integration of local culture values and character values, and language provided by experts judgment checklist that can be seen in the Appendix of this thesis.

There are three components of the experts' judgment checklist as the guidance for the expert to assess the textbook. The three components were contents, integration of local culture and presentation and language provided. Therefore, the amount of all items was 29 
items. The scale that was used in the checklist was 1-4, which 1 means poor, 2 was enough, 3 was good, 4 was very good. The results of the rubric were analysed to know the experts' evaluation regarding to the materials. And then the analysed results were categorized into one of the following rating scale; Excellent Material, Good Material, Below Material, Below Average Material, and Poor Material.

The first step was found the reliability of the expert judgment's result. The reliability of the data was tested by using SPSS16 and using Cronbach's Apha coefficient.

The researcher used categories of reliability value by George and Mallery (2003) as cited in Gliem and Gliem (2003) to interpret the meaning of Cronbach'a alpha coefficient. George and Mallery proposed six categories of reliability of data that are used to interpret the meaning of Cronbach's Alpha coefficient.

Based the categories of data reliability, the result of the expert judgment used in this study is categorized as acceptable since the value of Cronbach's Alpha coefficient of the data is 0.75 . The meaning is the data of the result of expert judgment form are accepted and it can be used in the study.

The results of the rubric were also analyzed to know the experts' evaluation regarding to the materials. . In finding the quality of the textbook, the formula proposed by Nurkancana and Sunartana (1992) were used. Then the analyzed results were categorized into one of the following rating scale; Excellent Material, Good Material, Below Material, Below Average Material, and Poor Material.

By the first expert, the result of the developed culture based English textbook analyzed by checklist for material development was 149. Based on the criteria of a good material as shown in the above table, the score indicated that the developed culture based English textbook was categorized as excellent learning material.

By the second expert, the result of the developed culture based English textbook analyzed by checklist for material development was 149. Based on the criteria of a good material as shown in the above table, the score indicated that the developed learning material was categorized as excellent learning material. Beside analyzed quantitatively, the data from the checklist also analyzed qualitatively based on the experts 'suggestion for revision of the textbook.

Beside analyzed quantitatively, the data from the checklist also analyzed qualitatively based on the experts 'suggestion for revision of the textbook. The analyzing is explained as follows.

1) The Result of First Expert

The first expert gave 4 points (excellent) for 34 items and gave 3 points (good) for 4 items of the checklist. Even though the first expert gave maximum point for most items, there were some revision that suggested by the expert. The suggestion and comments about the textbook is explained as follows.

\section{a. Content}

The textbook begins with an introduction, and how to use the textbook. The introduction was correct but there were some grammatical mistakes in it. Therefore, it was advised by the experts to revise all the grammar mistakes. It was very important to ensure that the textbook is free from any grammatical mistakes.

There were some incomplete sentences. Some reading passages were ended by incomplete sentences. The expert suggested to complete those incomplete sentences by rewriting the reading passage and found the appropriate ending for those reading passage.

The part "Let's Get Inspired" is expected can motivate students to learn some good characters that had by inspiring person. It was better if the researcher to put inspiring person which had relation with the material and make a follow up activity about that part. It was important in order to make line between material and inspiring person. So the part "Let's Get Inspired" could support the material.

Some comments were made in terms of the dictions of the content. The experts gave advice to choose appropriate 
diction which was suitable to the students' level. There were several dictions that too difficult for first junior high school students to be understood.

Another positive feedback was given by expert in terms of contents. The experts gave positive comment about the learning materials which are in line with the syllabus. However, there was a comment about an activity in Unit II especially in song "Saying I am Sorry" about the lyric. The 3rd lyric was not united to whole song's lyric.

b. Language

There was no serious comment about the language used in the textbook. There were about some grammatical mistake and missed word of so sentences. The expert suggested revising all the mistakes.

2) The Result of Second Expert

The second expert gave 4 points (very good) for 35 items and 3 points (good) for 3 item of the checklist. There were some revision that suggested by the expert. The suggestion and comments about the textbook is explained as follows.

a. Content

The textbook begins with an introduction, the introduction was correct but there were some grammatical mistakes in it. Therefore, it was advised by the experts to revise all the grammar mistakes. It was very important to ensure that the textbook is free from any grammatical mistakes.

The expert advised about the chosen name in the textbook. There were many similar Balinese name, and the expert gave advice to chose another Balinese name to put in textbook. There were also foreigner name that did not appropriate with their country. It $s$ important to put foreigner name that appropriate with characteristic name of that country.

Another comment was given by the second expert about the clarity of activity. There was some activity were not clear for the students and have no significant for students competence. It is important to make activity that have clear instruction and gave a significant effect for the students' competence.

\section{b. Presentation Aspect}

In presentation aspect there was no serious revision to be applied for presentation aspects. Both of experts agreed that the presentation already good for textbook. The experts' feedback and suggestion only related to the line which is used to write by students. It is better to put line in box to make students easier in write the answer and it will be neater.

\section{c. Language}

There were some comment about some grammatical mistake and word arrangement. The expert suggested revising all the mistakes.

\section{Evaluating the Product}

Evaluating testing result was done after all the expert judgment forms are obtained. Those expert judgment forms were checked in order to find the validity and the reliability. Aside from that, evaluating testing result was also done through the revision of the textbook based on suggestions that were given by the experts.

In the expert judgment form, the experts were given chances to give feedbacks, suggestions, and comments. The feedbacks, suggestions, and comments from the experts were used by the researcher to revise the textbook

Based on the results of those evaluations, there were also some weaknesses that should be revised by the writer in order to make the textbook is better. A further analysis was done to check and revise again every page of the textbook to ensure that no mistakes remained. Some modifications were made based on the responses given by the experts. The brainstorming section was revised, some activities were revised, the margin was revised and some grammatical mistakes were corrected.

\section{CONCLUSIONS}

Based on the result of this research and development, some points can be concluded that:

This culture-based English textbook is a suitable learning material 
which was designed for 1st semester grade VII students of Junior high school based on the appropriateness with the curriculum, the local culture values, and the criteria of good learning material. This textbook was proved acceptable to be used by the result's evaluation of the experts which judged the textbook and categorized the product became very good learning material. The quality of the textbook was validated by the expert judgment validation. The result of the expert judgment validation showed that the product had a good quality and the development of Culture Based English Textbook for first Semester Grade VII Students of Junior high school in Buleleng was succeed.

\section{SUGGESTIONS}

This research aimed at developing an English textbook which is based on the Balinese culture values to teach $1 \mathrm{st}$ Semester Grade VII students of junior high school. Based on the study conducted, there are some suggestions that can be proposed:

1. For Students

It is suggested for the students to use the culture based textbook to enable them learning English through Balinese local culture values. Furthermore, the users of this culture based English textbook are expected to develop the materials of this textbook based on the characteristics of the special culture where the textbook is used.

2. For English Teacher

The teachers are expected to keep trying developing the materials of this culture based English textbook to create more interesting and innovative learning activities which are very beneficial for the students who use this textbook so the quality of the culture based English textbook can be subsequently improved.

\section{For Other Researchers}

Since the product of this study was supplementary textbook, it might need further improvement because the time using for data-taking of this study was very short. Further research on this topic is still needed to know the effectiveness of the textbook toward the development of students' achievement in learning English and character education. Since every part of region has them special culture that differs from the other part of Bali. Other researchers are expected to keep trying developing the materials of this culture based English textbook to create more interesting and innovative learning activities

\section{REFERENCES}

Balitbang Puskur. 2010. Pengembangan Pendidikan Budaya dan Karakter Bangsa: Pedoman Sekolah. Jakarta: Kemdiknas Balitbang Puskur. Retrieved from www.balitbang.depdiknas.go.id/?p $=246$

Ellis, T. J., \& Levy, Y. (2010). A Guide for Novice Researchers: Design and Development

ResearchMethods.Retrieved April 1, 2015 from http://proceedings.informingscience. org/InSITE2010/InSITE10p107118Ellis725.

Kristiawan, D., Y. (2012). Situating Local Culture In ELT Material Design In The Indonesian EFL Context. The English Teacher, XLI (2), 174-185

Mahardana, Agus. 2011. Developing a Culture Based English Module for Grade V of Elementary School in Bali. Singaraja: Universitas Pendidkan Ganesha.

Marlina, M. E. (2014). Kurikulum 2013 yang Berkarakter, JUPIIS Volume 5 Nomor 2, 2013, hlm. 27.

Mufidah.(2014).

Kurikulum 2103.http://bulekh.blogspot.com/20 14/03/makalah-kurikulum-2013. Accessed on October 24, 2014

Panduan Pendidikan Karakter di Sekolah Menengah Pertama (2010). Jakarta: Kementrian Pendidikan 
dan Kebudayaan Nasional. Direktorat jenderal Manajemen Pendidikan dan Menengah.

Pedoman Pelaksanaan Pendidikan Karakter (2011). Jakarta: Kementerian Pendidikan dan Kebudayaan Nasional.

Permendikbud No. 71 Tahun 2013 tentang Buku Teks Pelajaran. Retrieved from

http://www.pendis.kemenag.go.id/p ai/file/dokumen/06.B.SalinanLampir anPermendikbudNo.64th2013ttgBu kudanTeks.pdf

Ranjit, S. (2010).How to Develop and Produce Simple Learning Materials with Limited Resources at Community Level. Retrieved April 1 , from http://www.accu.or.jp/litdbase/pub/ dlperson/pdf0106/rpp25.pdf

Soekanto, S. (1990).Sosiologi : Suatu pengantar (4th nd). Jakarta : RajaGrafindo Persada

Sudrajat, Ajat. (2012). Mengapa Pendidikan Karakter ?.Retrieved March 20, from http://staff.uny.ac.id/sites/default/fil es/Mengapa\%20Pendidikan\%20Ka rakter.pdf.

Sukarno. (2012). Integrating Local Cultures In Teaching English As A Foreign Language For Character Building. Jurnal Pendidikan Karakter, II (2), 202-2012

Tomlinson, B (1998). Glossary of basic terms for materials development in language teaching and introduction.In B. Tomlinson (ed.), Materials development in language teaching. (pp. 1-24). Cambridge: Cambridge University Press

Turkan, S., \& Celik, S. (2007). Integrating Culture into EFL Texts and Classrooms: Suggested Lesson
Plans. Online Submission, 1(1), 1833.

Undang-Undang No. 20 Tahun 2013 Sistem Pendidikan Nasional. Retrieved from http://sipma.ui.ac.id/files/dokumen/ U SNP SN\%20PT/PP\%20SNP/P P0322013 SNP.pdf

Undang-Undang No. 14 Tahun 2005 Kompetensi Guru 
Lingua Scientia Vol. 23 No. 2 December 2016 